\title{
O uso de precedentes estrangeiros e a de- claração de Estado de Coisas Inconstitucionais pelo Supremo Tribunal Federal
}

\section{The use of foreign precedents and the State of Unconstitutional Things declaration by the Federal Supreme Court}

Juraci Mourão Lopes Filho ${ }^{1}$

Isabelly Cysne Augusto Maia ${ }^{2}$

Resumo: O Supremo Tribunal Federal declarou, em 2015, o Estado de Coisas Inconstitucionais (ECI) no Brasil por meio do julgamento da medida cautelar na Ação de Descumprimento de Preceito Fundamental (ADPF) $n^{\circ} 347$. Reconheceu-se a existência de um quadro de violação massiva dos direitos fundamentais de presos no sistema carcerário nacional, inovando, assim, o controle abstrato de constitucionalidade no Brasil. Foi feita expressa invocação de precedente

1 Doutor em Direito Constitucional (UNIFOR), Mestre em Direito (UFC), pós-graduado lato senso em Direito Processual Civil. Professor do programa de pós-graduação stricto sensu do Centro Universitário Christus - UNICHRISTUS. Procurador do Município de Fortaleza. Advogado. E-mail: juracimourao@gmail.com

2 Mestranda em Ordem Jurídica Constitucional pela Universidade Federal do Ceará. Pós - Graduanda em Direito Administrativo pela PUC-Minas. Graduada em Direito pela Universidade Federal do Ceará. Advogada no escritório Cintra Mourão Advogados. E-mail: isabellycysne@gmail.com 
da Corte Constitucional Colombiana, que criou e desenvolveu o ECI por sua jurisprudência. Com essa decisão, o Supremo adotou prática cada vez mais comum em várias cortes de competência constitucional pelo mundo, consistente em invocar precedentes estrangeiros. $\mathrm{O}$ presente artigo se propõe, então, a analisar essa prática do uso de precedentes estrangeiros, descrevendo as principais correntes teóricas a respeito e propor um modelo próprio, que traga os parâmetros adequados para uma prática correta e ajustada à realidade brasileira. Conclui-se que esses critérios são de ordem hermenêutica e substancial e evidenciam que o Supremo Tribunal Federal não os observou por completo quando da declaração do Estado de Coisas Inconstitucionais, sendo um dos motivos para a baixa eficácia da decisão, inclusive enquanto precedente interno.

Palavras-chaves: Precedentes estrangeiros. Estado de Coisas Inconstitucionais. Hermenêutica.

Abstract: The Federal Supreme Court has declared in 2015 the State of Unconstitutional Things (ECI) in Brazil by judging the preliminary injunction in the ADPF $n{ }^{\circ} 347$. It was recognized that there was a massive violation of the fundamental rights of prisoners in the national prison system, thus innovating the abstract control of constitutionality in Brazil. A precedent from Constitutional Court of Colombia was invoked, because that court has created and developed the ECI by multiple judgements. The Federal Supreme Court has adopted in this decision an increasingly common practice in several constitutional courts around the world: the use foreign precedents. The present paper intends to analyze this practice of using foreign precedents, describing the main theoretical patterns and proposing a new model, that brings the appropriate 
parameters to a correct and adjusted practice to the Brazilian reality. It is concluded that these criteria are of a hermeneutical and substantial nature and they show that the Federal Supreme Court did not fully observe them to declare the State of Unconstitutionality, which is one of the many reasons for the low effectiveness of the decision, even as an internal precedent.

Keywords: Foreign precedents. State of Unconstitutional Things. Hermeneutics.

\section{INTRODUÇÃO}

Em setembro de 2015, o Supremo Tribunal Federal declarou o Estado de Coisas Inconstitucionais (ECI) no Brasil por meio do julgamento da medida cautelar na Ação de Descumprimento de Preceito Fundamental (ADPF) $n^{\circ}$ 347. Reconheceu-se judicialmente, nessa ação ajuizada pelo Partido Solidariedade e Liberdade - PSOL, a existência de um quadro de violação massiva dos direitos fundamentais de presos no sistema carcerário nacional, sobretudo no que tange a sua dimensão objetiva, em razão da atuação omissiva ou ineficiente dos poderes Legislativo e Executivo de todos os Estados-membros e da União Federal.

Foi decisão inédita na jurisdição nacional, tomada com expressa invocação de precedente da Corte Constitucional Colombiana, que no ano de 1997 declarava o mesmo em face de caos similar no sistema carcerário da Colômbia. Desde aquela data, a corte constitucional daquele país vem proferindo declarações de Estado de Coisas Inconstitucionais, sendo verificado mesmo uma evolução jurisprudencial do instituto, que foi ignorada pelo Supremo Tribunal Federal quando fez importação do instrumento. 
Para se conhecer acertadamente o ECI cabe, então, observar sua origem, contornos e limitações, destacando a validade, limites e o modo mais adequado de se usarem precedentes estrangeiros, prática cada vez mais comum nas cortes constitucionais de vários países, para que se possa obter o máximo de eficácia a partir da experiência estrangeira. Este é o ponto: o recurso à jurisprudência de outro país só tem real valia caso se observe toda a experiência com o assunto; não só o isolado raciocínio jurídico contido em um jugado, mas também, e talvez principalmente, as premissas expressamente adotadas e aquelas subjacentes e implícitas, as consequências observadas e a evolução ocorrida - tudo em atenção ao contexto social que direta ou indiretamente pode influenciar no jogo hermenêutico. Só com esse máximo escrutínio de toda substância hermenêutica será possível apreender e importar adequadamente o contributo que a experiência alienígena pode dar ao direito nacional.

O presente artigo se propõe, então, a analisar o uso de precedentes estrangeiros por várias cortes de competência constitucional pelo mundo, a fim de investigar as principais correntes que teorizam sobre esse fenômeno e propor um modelo próprio, que traga os parâmetros adequados para uma prática correta e ajustada à realidade brasileira. Propostos os critérios (que, adiante-se, são de ordem hermenêutica e substancial), será investigado se o Supremo Tribunal Federal os observou quando da declaração do Estado de Coisas Inconstitucionais e quais os ajustes e desajustes encontrados.

\section{QUADRO ATUAL DO USO DE PRECEDENTES ESTRANGEIROS}

Não se pode proceder a uma eficiente análise da decisão cautelar na ADPF 347 sem se enfrentar, preambularmente, 
o tema do uso de precedente estrangeiro, porquanto a experiência colombiana foi expressamente apontada tanto pelo partido autor da ação quanto pelos Ministros em seus votos. Mais precisamente, o próprio fundamento da pretensão e a possibilidade de o Judiciário declarar o Estado de Coisas Inconstitucionais têm por base as decisões da Corte Constitucional Colombiana que são citadas.

Não se trata, pois, de uma citação aleatória, fruto de escolha arbitrária entre vários tribunais do mundo a fim de se pleitear uma tutela jurisdicional já corriqueira na ordem jurídica nacional; ao contrário, tem-se a indicação de uma experiência bem delimitada que se busca, desde a propositura da ação, reproduzir no Brasil de maneira inédita. Além disso, não se trata de uma ampla análise do direito comparado, com a invocação de instrumentos legislativos, constitucionais ou, ainda, de concepção acadêmica pura de lá. A importação é bem delimitada nesta ocasião: relaciona-se a objeto específico, delineado por uma produção precipuamente jurisdicional, sendo os precedentes invocados o cerne da questão.

Ao agir assim, tanto o autor quanto o Supremo Tribunal Federal adotam a prática cada vez mais comum em várias cortes de competências constitucionais de diversos países, consistente em buscar precedentes de tribunais congêneres de outras nacionalidades. Esse intercâmbio jurisprudencial se insere em um âmbito maior de um constitucionalismo mundial, segundo expressão utilizada por Bruce Ackerman em trabalho de referência nas discussões anglo-saxônicas ${ }^{3}$. Leonel Severo Rocha e Fernando Tonet ${ }^{4}$ aludem à intercons-

3 ACKERMAN, Bruce. The Rise of World Constitutionalism. 83 Va. L. Rev. 771 (1997).

4 ROCHA, Leonel Severo, TONET, Fernando. A interconstitucionalidade como produção jurídica descentralizada dentro das novas observações 
titucionalidade, da seguinte maneira:

Atualmente, não se pode falar em um constitucionalismo, mas em vários constitucionalismos, nesse sentido a interconstitucionalidade, por estar baseada em múltiplos contextos civilizacionais, mostra-se como uma forte teoria constitucional, pois automiza-se ao se reproduzir com as experiências advindas da sociedade multicultural, bem como pelas exigências do Estado.

Segundo Rui Cunha Martins, a interconstitucionalidade é o constitucionalismo formado por várias vozes, onde dentro do fogo cruzado de nações, territórios e governos, surge uma norma descentralizada que busca o diálogo constitucional contextural, acima do monólogo constitucional dirigente.

Marcelo Neves, por sua vez, alude a um transconstitucionalismo ${ }^{5}$, que tem como uma das experiências marcantes entre os estados latino-americanos o diálogo buscado sobre a temática entre os estados, especialmente por suas cortes com competência constitucional.

Neves destaca que isso é corroborado por uma característica dos países da região: “Na América Latina, há também uma velha tradição de referências a dispositivos, jurisprudências e doutrinas constitucionais estrangeiras" 6 . De fato, na formação dos estados da região, por exemplo, a experiência estadunidense foi corriqueira fonte de inspiração. No caso brasileiro, demonstra-se isso, quando da instauração da República, com edição do Decreto $n^{\circ} 848$, de 1890, que disciplinava a Justiça Federal. Seu art. 386 dispunha que "os estatutos dos povos cultos e especialmente os que

estatais. Revista Brasileira de Estudos Políticos | Belo Horizonte | n. 115 | pp. 473-496 | jul./dez. 2017.

5 NEVES, Marcelo. Transconstitucionalismo. São Paulo: Martins Fontes. 2012.

6 NEVES, Marcelo. Do diálogo entre as cortes supremas e a Corte Interamericana de Direitos Humanos ao transconstitucionalismo na América Latina. Revista de Informação legislativa. Ano 51, Número 201, ja/mar. 2014.

P. 193-214. 
regem as relações jurídicas na República dos Estados Unidos da América do Norte, os casos de common law e equity, serão também subsidiários da jurisprudência e processo federal". Mais recentemente, no entanto, a influência do direito europeu, especialmente de origem alemã, tem sido determinante em toda a região.

Roberto Dias e Michael Freitas Mohallem ${ }^{7}$ buscam evidenciar esse transconstitucionalismo apontando: a) a assinatura de tratados internacionais de direitos humanos pelos vários estados da região latino-americana; b) as variadas previsões constitucionais de internalização dessas disposições na ordem nacional, inclusive com status jurídico privilegiado; e c) a busca de diálogo entre os tribunais com competência constitucional, não só mediante a consulta recíproca de jurisprudência, mas também por vários encontros presenciais, como a Conferência Mundial sobre Justiça Constitucional, Fórum Permanente de Cortes Supremas do Mercosul e a Conferência das Jurisdições Constitucionais dos Países de Língua Portuguesa. O autor aponta para a formação de uma comunidade internacional de cortes de jurisdição constitucional.

Esse é um quadro inegavelmente existente, mas concluir, a partir dele, que exista efetivamente uma comunidade internacional de tribunais é uma visão um tanto quanto idealizada a seu respeito. Os tribunais se conhecem cada vez mais, se encontram e debatem, mas afirmar, por exemplo, que o Supremo Tribunal Federal busca construir um discurso convergente e coordenado com os tribunais congêneres mesmo da América do Sul contém uma certa dose de en-

7 DIAS, Roberto; MOHALLEM, Michael Freitas. O diálogo jurisdicional sobre direitos humanos e a ascensão da rerde global de cortes constitucionais. In PIOVESAN, Flávia. SALDANHA, Jânia Maria Lopes. Diálogos jurisdicionais e cortes constitucionais. São Paulo: Gazeta Jurídica. 2016. 
tusiasmo com o assunto. Mesmo na citação de precedentes estrangeiros é muito mais comum a citação de casos da US Supreme Court, do Tribunal Federal Constitucional alemão ou a Corte Europeia de Direitos Humanos do que exposições sobre a jurisprudência argentina, uruguaia ou de qualquer outro país vizinho. Tem se tornado corriqueiro, entretanto, encontrar citação de precedentes estrangeiros, mesmo que não estejam inseridos em um sistema supranacional como o verificado na América Latina, em que se busca uma convergência principiológica em torno de direitos humanos.

Essa não é uma prática adotada por tribunais de países periféricos, que possa ser tomada como reflexo de algum tipo de subserviência cultural ou política a países desenvolvidos. Também não se trata de ex-colônias buscando direito da antiga matriz para preencher lacunas em seu ordenamento. Mesmo em países centrais, como os EUA e Canadá, tem-se verificado esse recurso para interpretar suas próprias constituições. Em casos como Lawrence v. Texas (referentes à criminalização de práticas homossexuais privadas) e Atkins v. Virgínea (que julgou inconstitucional a aplicação de pena de morte a deficientes mentais), a US Supreme Court invocou expressamente julgados da Corte Europeia de Direitos Humanos ao deliberar. E esses não são casos isolados. Stefano Bertea e Claudio Sarra ${ }^{8}$ arrolam vários outros em que, de maneira mais ou menos detida, foram feitas alusões a julgados de outras ordens jurídicas: New York v. United States, 326 U.S. (1946); Filartiga v. Pena-Irala 630 F.2d 876 (2nd Cir. 1980); Kadic v. Karadzic, 70 F.3d 232 (2nd Cir. 1995); Abebe-Jira v. Negewo, 72 F.3d 844 (11th Cir. 1996); Printz v. United

8 BERTEA, Stefano, SARRA, Claudio, Foreign Precedents in Judicial Argument: A Theoretical Account (July 16, 2014). University of Leicester School of Law Research Paper No. 14 $\square$ 20. Available at SSRN: https://ssrn.com/ abstract=2467155 or http://dx.doi.org/10.2139/ssrn.2467155. 
States, 521 U.S. (1997); Washington v. Glucksberg, 521 U.S. (1997) e Knight v. Florida, 528 U.S.

Ane-Marie Slaughter ${ }^{9}$ alude a uma fertilização constitucional cruzada (constitutional cross-fertilization) para aludir a esse fenômeno. Se a US Supreme Court já exercia influência sobre outras cortes da tradição do common law, especialmente após a Segunda Guerra Mundial, ela também passou a sofrer influência de outros tribunais. Especialmente em assuntos relacionados a direitos humanos, como pena de morte e direitos à privacidade. Menciona-se, por isso, uma teoria mundial e o estabelecimento de um diálogo, e não da mera recepção unilateral e surda, entre várias cortes com competência constitucional. A autora compartilha do entusiasmo de Roberto Dias e Michael Freitas Mohallem e indica a formação de uma comunidade mundial de tribunais. Escreve:

In sum, the awareness of constitutional cross-fertilization - an awareness of who is citing whom among the judges themselves, and a concomitant pride in a cosmopolitan judicial outlook - creates an incentive to both lender and borrower be, leading to dialogue rather than monologue, and deliberation rather than gap-filling. This momentum may result in unprecedented judicial jockeying, in which outlier courts deliberately seek to reestablish their place in a global judicial community. Equally important to this cross-fertilization, however, is a transjudicial debate about the uses and abuses of persuasive authority, in which individual courts seek to draw a line between the requirements of their own legal systems and the resources of others.

A despeito de haver graves resistências a essa prática, não só por parte de integrantes dos tribunais como também de constitucionalista, há indícios, como destaca John $\mathrm{Yoo}^{10}$,

9 SLAUGHTER, Anne-Marie. A Global Community of Courts. 44 Harvard International Law Journal 191 (2003)

10 YOO, John, Peeking Abroad?: The Supreme Court's Use of Foreign Precedents in Constitutional Cases. University of Hawaii Law Review, 2004. 
de ela não ser meramente ornamental, tendo os precedentes estrangeiros efetiva influência sobre os vereditos. Primeiro, no caso americano, a própria resistência de alguns Justices da US Supreme Court evidencia que não é algo irrelevante, que não tenha efetivamente influenciado o convencimento dos julgadores. Segundo, porque há acadêmicos propondo enfaticamente como projeto teórico que a Suprema Corte estadunidense trave, de fato, um diálogo internacional, como os já aludidos Bruce Ackerman e Ane-Marie Slaughter.

Bruce Ackerman, com a citada ideia de um constitucionalismo mundial, destaca que a "esperança iluminista em torno de constituições escritas está varrendo o mundo", tendo cortes constitucionais fortes na Alemanha, Espanha, Itália, Israel e Hungria. Diante disso, se contrapõe ao comportamento de profissionais do Direito nos EUA estarem, no dia a dia, um tanto quanto ainda alheios a essas inspirações mundiais, mantendo uma visão autorreferente do constitucionalismo e do papel da corte de ápice. Propõe o efetivo ingresso dos EUA nesses diálogos.

John Yoo, contudo, se opõe à prática por três razões, ao menos para a realidade estadunidense e no concernente à interpretação de sua Constituição. As duas primeiras são razões formais, relacionadas (1) à falta de delegação de autoridade pela carta americana aos tribunais estrangeiros e (2) à delegação interna de poderes. Especificamente sobre o controle de constitucionalidade e a distribuição interna de competências, Yoo relembra que no seminal precedente Marbury v. Madison viabilizou-se a invalidação de lei infranconstitucional utilizando o critério do desborde das competências delegadas pelo povo para as autoridades constituídas. Assim, ao se valer de precedentes formados em face de outros documentos jurídicos, a Suprema Corte

Available at SSRN: https://ssrn.com/abstract $=615962$ 
estaria atuando fora de sua função de proteger a constituição americana e não qualquer outro estatuto normativo, na específica maneira que ela delegou os poderes conferidos pelo povo a suas autoridades.

A terceira razão para a oposição de Yoo é material, decorrendo de fortes divergências históricas e políticas entre Europa e Estados Unidos, as quais justificariam evitar a transferência de ideias do velho continente para o novo mundo. Ele cita a estabilidade institucional norte-americana nos últimos duzentos anos, mediante a manutenção de um modelo lockeano de separação de poderes, o federalismo e seu próprio Bill of Rights; enquanto, durante o mesmo período, a Europa passou por convulsões intestinas, tendo apelado a ideologias extremadas como o comunismo e o nazismo, os quais, destaca, mataram milhões de pessoas. Conjectura as consequências de a Suprema Corte ter importado, naquele período, precedentes de tribunais nazistas ou comunistas que, na ocasião, pareciam avançadas.

Além disso, destaca que esse modelo de integração internacional é próprio da Europa. Tem sido a tônica utilizada por seus países para evitar os históricos conflitos internos, o que diverge, e mesmo é possibilitada, a seu ver, pela política internacional americana. Segundo o autor, esse modo de integração é um luxo permitido pela atuação americana, que não pode, no entanto, ser por ele seduzido. Escreve:

The large gap in power between the United States and Europe is perhaps even more apparent qualitatively; the United States has become the "indispensible nation" without which Europe could not even handle the internal civil war along its borders in Kosovo. Only the United States has the power to project power globally or to fight more than one large regional war at the same time. Without the United States' willingness to engage in power politics, Europe would not have had the luxury to integrate. If this is correct, then European constitutional values are particularly 
inappropriate for the United States. They have been developed and enjoyed because their governments enjoy a different tradeoff between national security on the one hand, and individual liberties and economic prosperity on the other. The United States, however, which has greater responsibilities for keeping international peace, and for guaranteeing stability in Europe, faces a different balance between national security demands and constitutional liberty.

Nessa linha, de raciocínio, e para demonstrar ainda a divergência de atuação internacional que a seu ver impede o uso de precedentes da Corte Europeia de Direitos Humanos, o autor chega a comparar o orçamento militar dos EUA com o da União Europeia, ressaltando, em outras palavras, que os EUA fazem o trabalho duro de assegurar a paz mundial de que desfruta a Europa para poder propor métodos mais brandos nas relações internacionais, como a integração e o transconstitucionalismo. Isso, na visão de Yoo, interfere no balanço entre liberdades e segurança nacional, que nos EUA tem equilíbrio diferente do europeu. Essas divergências históricas, culturais e de geopolítica seriam, pois, motivos substanciais suficientes para se evitar, ao menos nos EUA, o recurso a precedentes estrangeiros.

Entre os justices da US Supreme Court, foi bem divulgado debate ocorrido em $2005^{11}$ entre dois deles com posições divergentes: Antonin Scalia, contrário à invocação de direito estrangeiro para interpretação da constituição americana, e Joseph Breyer, a favor da prática.

Scalia descreve três visões de se interpretar a constituição norte-americana: a) historicamente, segundo o que é chamado de originalismo, em que se tenta compreender o

11 DORSEN, Norman. The relevance of foreign legal materials in U.S. constitutional cases: A conversation between Justice Antonin Scalia and Justice Stephen Breyer. International Journal of Constitutional Law, Volume 3, Issue 4, 1 October 2005, Pages 519-541, https://doi.org/10.1093/ icon/moi032. 
que se quis prescrever quando da adoção da constituição e não no momento atual, sendo necessário traçar uma rígida distinção entre interpretar e reescrever o texto constitucional; b) interpretar a constituição buscando os padrões morais americanos vigentes no presente; e c) buscando qual a melhor solução para o caso, não segundo o que foi posto pelos autores da constituição, não segundo os padrões morais vigentes, mas segundo a melhor maneira que o juiz possa agir para obter essa solução, inclusive buscando as opiniões de outros juízes e estudiosos pelo mundo.

No primeiro caso, o único direito estrangeiro que importaria, segundo Scalia, seria o antigo direito inglês, vigente anteriormente à constituição americana e que permite entender algumas expressões originais como due processo of law ou right of confrontation. Ele destaca que nos federalist papers havia vasta citação de direito estrangeiro, mas naquela ocasião se tinha em mente escrever uma nova Constituição e não interpretar uma já adotada. A segunda visão exclui, por definição, o direito estrangeiro, porque foca nos padrões específicos da sociedade americana. Apenas a terceira perspectiva autoriza a busca pelo direito estrangeiro, mas, a seu ver, é uma visão que pressupõe os juízes, oriundos de uma camada bastante específica e aquinhoada da população estadunidense, estarem em uma melhor posição em relação a qualquer outro cidadão ou autoridade pública para interpretar a constituição, enquanto, na verdade, eles são peças em um jogo muito mais amplo que debate e interpreta a Constituição.

É fácil perceber que a oposição de Scalia diverge em parte de Yoo, pois o Justice não indicou questões formais de delegação de poderes, mas uma perspectiva substancial que parte de uma questão hermenêutica: qual a maneira adequada de se interpretar a Constituição americana? E a relevância ou irrelevância do direito estrangeiro deriva diretamente 
do paradigma interpretativo adotado. Não se trata, pois, de um desacordo fático ou jurídico, mas eminentemente de moralidade e fidelidade, refletindo concepções diferentes do que seja o Direito de um modo geral e uma constituição de uma maneira mais específica. Tem-se, assim, um desacordo de ordem profunda.

A oposição exposta por Scalia também se funda na arbitrariedade de escolha de qual precedente estrangeiro selecionar e em que tribunal, deixando a prática sujeita a manobras, porque se citam apenas casos que reforçam o entendimento já adotado pelo julgador. No debate, é destacado não se encontrar nos votos de Breyer referência a cortes sul-americanas, asiáticas ou mesmo mulçumanas. Para Scalia, essa arbitrariedade é o maior risco.

Por outro lado, Breyer sustenta que questões submetidas à Suprem Court são similares a outras já enfrentadas por outros países, e, em se verificando no exemplo estrangeiro uma análise arguta e inteligente, não haveria nada a impedir seu uso, justamente porque incementa a compreensão de problemas, que seriam próprias do ser-humano, independentemente de sua nacionalidade. Isso em vez de representar uma subjetividade do julgador, demonstra uma busca de uma visão pública geral sobre o tema. A maneira de Breyer encarar a citação de direito estrangeiro nos escritos federalistas é completamente distinta, pois, para ele, evidenciaria que os fundadores da nação norte-americana consideram que há problemas comuns a todos os humanos. Em suas palavras:

[...] I did think that the issue is not technically legal, but rather a law-related human question, and all concerned, American and foreign judges alike are human beings using similar legal texts, dealing with a somewhat similar human problem. Reaching out to those other nations, reading their decisions, seems useful, even though they cannot determine the outcome of a question that arises under the American Constitution. 
Esse é um ponto importante na posição de Breyer e que será explorado no ponto seguinte deste texto, consistente na premissa de que há o compartilhamento internacional de princípios. Breyer mesmo defendendo a prática, reconhece, no entanto, que não toma o precedente estrangeiro como formalmente vinculante, o que não retira a validade de seu uso, justamente por viabilizar a utilização de um caso em que já tenham argumentos e contra-argumentos amadurecidos e apreciados.

É preciso analisar com atenção os argumentos de Yoo, Scalia e Breyer. Há realmente uma barreira formal relacionada à delegação de jurisdição a cortes de países estrangeiros: não existe uma vinculação formal. Não se pode invocar qualquer tipo de ascendência jurídica de tribunais estrangeiros sobre os nacionais para justificar uma força vinculante. Essa observância não pode se dar por causa de qualquer tipo de autoridade da corte alienígena. Quando muito, e a depender do caso concreto, é possível se falar de algum tipo de vínculo formal a uma corte internacional, cuja jurisdição tenha sido reconhecida por um estado signatário de tratado internacional devidamente internalizado em sua ordem jurídica. É justamente o exemplo da Corte Europeia de Direito Humanos, cujos precedentes possuem força vinculante formal sobre os tribunais de países europeus que voluntariamente reconheceram sua autoridade mediante tratado. Não só o comando de uma respectiva sentença dessa corte internacional merece deferência e cumprimento, a decisão também não poderá ser ignorada, enquanto precedente, em futuros julgamentos dos tribunais nacionais, justamente ante a possibilidade de se acessar a corte europeia para reformá-las.

Isso impõe a divisão entre precedentes estrangeiros (de tribunais internos de país alienígenas) e precedentes internacionais (de cortes internacionais criadas por tratados 
de que é signatário o país que invoca o precedente). Foca-se, neste estudo, nos precedentes estrangeiros, que, de fato, não desfrutam de qualquer força formal para se fazer útil em julgamento posterior de outro país. Em relação esses precedentes, não existe recurso ou outro meio processual de se acessar a corte emissora em busca da reforma da decisão nacional que não os observou.

Os precedentes estrangeiros se mostram úteis, portanto, não por questões formais de reconhecimento da superioridade hierárquica de outra corte acessível mediante recurso hábil a cassar a decisão recorrida, mas por razões substanciais, que não são obstadas pelas duas primeiras colocações de Yoo, concernentes à falta de delegação a autoridades por parte do documento constitucional.

Com efeito, percebe-se empiricamente que o tribunal de um país não invoca precedentes de outros locais por qualquer sorte de deferência a sua autoridade, mas para colher naquela experiência elementos hermenêuticos que podem causar um ganho interpretativo, no sentido de não ter que percorrer toda a cogitação de vários argumentos e contra-argumentos que possam ter sido enfrentados no caso anterior, ou revelar melhor algum aspecto das várias questões que podem incidir no julgamento. Servem ainda para compreender todas as implicações do entendimento que pode ser adotado e seus efeitos. A força vinculante, assim, é de natureza hermenêutica, racional ou argumentativa, em função de um compartilhamento de princípios incidentes em ambos os casos, o que se mostram com mais ênfase em julgamentos envolvendo direitos humanos.

A vinculação de qualquer precedente, mesmo nacional, depende não só de seu pedegree, mas também de sua substancia, em um balanço entre os elementos formais e materiais que o compõem. Por isso, não se pode laborar com a dicotômica 
divisão entre precedentes vinculantes (plenamente cogentes, assim reconhecidos apenas em atenção à autoridade que o produz ou imposição normativa, independentemente de seu conteúdo ou correção) e persuasivos (que se seriam utilizáveis apenas como um reforço argumentativo a critério do julgador). Há uma força variável, que depende justamente da composição entre elementos formais e substanciais.

Um precedente injusto, que não seja íntegro nem coerente ou que de alguma maneira não satisfaça uma pretensão de correção, tende a se fazer irrelevante, mesmo se oriundo de tribunal nacional de ápice. A perda de relevância ocorre se não abruptamente, por certo paulatinamente. Sua superação pode se dar não apenas por um overruling da própria corte, em um determinado momento, mas ser erodido aos poucos por sucessivos desafios de cortes inferiores, sem falar de uma superação legislativa, própria de um backlash, fenômeno já bem identificado e descrito pela doutrina constitucionalista.

Do mesmo modo, julgamentos que bem captam os valores de um período e estão integrados com as várias decisões políticas de uma comunidade de princípios, de modo a bem alinhar justiça e Direito, lei e realidade, se torna um símbolo que dificilmente pode ser olvidado independentemente de uma autoridade formal ou grau hierárquico do tribunal emissor. Entre esses dois extremos, do precedente formalmente vinculante, mais iníquo, ao precedente sem autoridade formal, mas justo, há um grande espectro de força vinculante variável.

Nessa escala, o precedente estrangeiro está mais próximo do extremo desprovido de força formal, daí depender mais de sua correção, justiça e do contributo interpretativo que tenha a oferecer do que qualquer imposição hierárquica ou autoritária, o que não é desprezível, conforme demonstra o exemplo da África do Sul. 
De fato, a constituição sul-africana é expressa em dispor que, em matéria de direitos fundamentais, é possível o recurso a direito estrangeiro. É o que se ler na Seção 39 (1):

When interpreting the Bill of Rights, a court, tribunal or forum(a) must promote the values that underlie an open and democratic society based on

human dignity, equality and freedom;

(b) must consider international law; and

(c) may consider foreign law.

Christa Rautenbach ${ }^{12}$, em análise desse dispositivo, ressalta os verbos auxiliares diferentes utilizados na alusão ao direito internacional e ao direito estrangeiro. Enquanto no primeiro se usa must, dando um sentido de dever, no segundo tem-se apenas may, que denota apenas uma possibilidade não obrigatória. De qualquer forma, tem-se um exemplo de ordem jurídica nacional que elide as oposições formais feitas por Yoo em relação à realidade americana. Na África do Sul, não se pode afirmar que há uma barreira constitucional de ordem formal que impeça a busca do direito estrangeiro. Ao contrário, há uma permissão expressa.

Rautenbach alude, contudo, que o permissivo constitucional é mais efeito do que causa, pois já havia uma arraigada tradição de uso de precedentes de outros países pelos tribunais sul-africanos, inclusive os de cúpula, sendo essa prescrição formal um mero reconhecimento de prática já antiga e arraigada por lá. Escreve:

For more than three hundred years the South African judiciary has, "with a minimum of fuss - and mostly without specific mention that they were doing so - adopted a comparative law approach"

12 RAUTENBACH, Christa. The South African constitutional court's use of foreign precedent in matters of religion: without fear or favour? Potchefstroom Electronic Law Journal/Potchefstroomse Elektroniese Regsblad. Vol 18, No 5 (2015) 
with regard to foreign precedent.1 The mixed nature (a mix of Roman-Dutch and English law) of South Africa's legal system necessitates a comparative legal approach to find, develop and make the law, and the South African courts were discreetly doing this behind the scenes, particularly since the unification of South Africa in the 1910s. They were consistently seeking guidance from foreign high court judgments, especially in the Commonwealth countries, the USA, the Netherlands, Germany, and other parts of Western Europe where the reception of Roman law also took place.

A autora fez levantamento nos julgados mais recentes e identificou que, de 1994 até 2010, a corte constitucional sul-africana proferiu 437 julgamentos. Em 223 deles, mais da metade, portanto, foram citados um total de 3.047 precedentes estrangeiros, o que evidencia uma intensa influência que, certamente, enriquece o trato hermenêutico e argumentativo da matéria, em havendo um uso adequado dos precedentes. Talvez por manter esse intenso diálogo internacional, a Corte Constitucional da África do Sul possui notabilidade mundial ao ponto de ser um dos tribunais mais referidos pela Suprema Corte dos Estados Unidos, ao lado da canadense, alemã, britânica e indiana, além da já aludida Corte Europeia de Direitos humanos ${ }^{13}$. A experiência sul-africana demonstra, pois, que, mesmo ante a ausência de qualquer barreira formal e expressa autorização de uso, o que importa são razões substanciais.

São possíveis, aqui, as primeiras conclusões parciais: a) em razão do compartilhamento mundial de ideias em torno de um constitucionalismo similar, tem havido uma intensa troca entre os países de um modo geral e, de maneira específica, entre os tribunais de competência constitucional; b) o

13 Cfr. Bertea, Stefano and Sarra, Claudio, Foreign Precedents in Judicial Argument: A Theoretical Account (July 16, 2014). University of Leicester School of Law Research Paper No. 14-20. Available at SSRN: https://ssrn. com/abstract=2467155 or http://dx.doi.org/10.2139/ssrn.2467155. Acesso em 18.jan. 2018. 
diálogo entre os tribunais se dá tanto por encontros presenciais quanto pela mútua referência jurisprudencial, ao ponto de haver um entusiasmo em torno de uma comunidade internacional de cortes; c) há na tradição latino-americana uma constante referência a direito estrangeiro, ainda que não entre países da região, sendo mais comum recentemente essa busca de diálogo jurisdicional; c) a prática, no entanto, não se restringe a países periféricos, sendo também comum em países centrais, como os EUA e o Canadá; d) as oposições apresentadas à tal prática são de duas ordens, (d.1) formal (ligadas a questão de delegação de competência e a falta do reconhecimento de uma deferência autoritativa à corte alienígena), (d.2.) materiais, de ordem hermenêutica (ligadas ao modo que se entende devido para interpretar a constituição e os direitos humanos) e fáticas (ligadas aos contextos que cercam os casos pretéritos e atuais); e) mesmo quem defende a aplicação dos precedentes estrangeiros, o faz por razões materiais, por considerar válidas as oposições formais.

Diante desse quadro, é preciso identificar quais os critérios ou elementos substanciais que orientam o uso de um precedente estrangeiro e como lidar com eles para que se tenham uma prática adequada. É o que se passa a analisar no tópico seguinte.

\section{OS CRITÉRIOS SUBSTANCIAIS PARA USO DE PRECEDENTE ESTRANGEIRO}

Os elementos de ordem substanciais que determinam a utilidade de um precedente estrangeiro e orientam seu efetivo uso dizem respeito ao conteúdo do julgado e a seu contributo hermenêutico para a solução de questionamentos jurídicos. Há vários fatores dessa natureza que podem se entrelaçar com questões formais, mas só na medida desses 
elementos materiais se fazem relevantes. Por exemplo, o tipo de processo em que o precedente foi produzido na origem só importa na medida do que é refletido em sua substancia. Um precedente ser fruto de um devido processo legal, em que tenha havido contraditório e a ampla defesa, só possui relevância na medida em que os argumentos e contra-argumentos surgidos ao longo do processo sejam efetivamente enfrentados e suficientemente apresentados no teor do julgamento, de modo a permitir a análise posterior. A similaridade social, jurídica e de moralidade política entre os dois países (o de origem do precedente e o de onde ele será aplicado), que evidencie um compartilhamento de princípios similares, também é indispensável, funcionando como um preâmbulo silencioso que viabiliza o próprio uso do julgado. Busca-se identificar, neste item, então, esses elementos, de modo que orientem o correto recurso ao precedente estrangeiro.

A proposta desses critérios que devem ser considerados expressamente na fundamentação da decisão e no arrazoado do advogado que invoque a seu favor a aplicação do precedente estrangeiro permite ainda a distinção entre o efetivo uso de um precedente daquilo que se pode chamar de mero exercício de erudição, consistente em apenas lançar mão do entendimento de uma corte de outro país. Utilizar um precedente é diferente desse recurso estilístico, não se confunde com mera alusão.

Essa citação ornamental, sem quaisquer consequências jurídicas mais determinantes em um julgamento, não se pode ter como razão efetiva para decidir, sob pena de nulidade, por falta da fundamentação adequada. O tribunal pode se valer desse recurso retórico, sem escrutínio dos elementos substanciais do precedente estrangeiro, se a decisão encontrar base suficiente em outra fundamentação autônoma. Se um juiz apenas aludir superficialmente a um precedente 
estrangeiro, ou seja, se ele genericamente disser que, por exemplo, a Corte Europeia de Direito Humanos já apresentou igual conclusão, mas sua decisão se calca em uma fundamentação adicional, autônoma e suficiente, não há uso adequado, mas também não se pode falar de nulidade da decisão, justamente por causa da fundamentação adicional e suficiente. No entanto, se essa mera alusão for a base do raciocínio decisório, a decisão é nula.

Por sua vez, o advogado que pincela decisões estrangeiras como simples reforço argumentativo, sem perquirir todos os elementos substanciais que autorizam o adequado uso no julgamento nacional, não poderá exigir posteriormente que o tribunal analise expressamente a incidência desse precedente estrangeiro de maneira específica e detida. Só será indispensável a análise das demais alegações autônomas e suficientes para embasar a pretensão.

É preciso atentar, porém, que esses dois métodos de se recorrer a precedentes (pelo uso adequado e pela invocação ornamental) nem sempre podem ser escolhidos livremente pelo julgador. Há casos em que o esquadrinhamento do precedente alienígena é obrigatório, o que ocorre por exigência de integridade transnacional, do contraditório e da ampla defesa ou quando a citação é a base da decisão. É demonstrativo de uma situação de uso obrigatório pelos dois fatores justamente o caso da ADPF $n^{0} 346$, em que a pretensão autoral já se fundava na jurisprudência colombiana, sendo base das razões da pretensão, além de ser questão indispensável para a própria atuação jurisdicional com vistas a declarar o estado de coisas inconstitucional. Além de ter havido a invocação expressa, é lícito afirmar que Brasil e Colômbia partilham de princípios comuns em torno de direitos humanos, o que é comprovado não só pelo fato de integrarem o sistema interamericano de direitos humanos, mas por similaridades históricas, sociais e culturais em grau 
suficiente para afirmar que integram uma mesma comunidade transnacional de princípios em torno do tema "direitos humanos". Em tal hipótese, haverá uma decisão omissa se nada for exposto a respeito do caso da Colômbia ou, em o fazendo, se der de modo retórico e ornamental.

É possível dizer, portanto, que se o precedente estrangeiro é fundamental e indispensável para o julgamento em razão de um dever de integridade ou do contraditório e da ampla defesa, por ter sido invocado detalhadamente por uma das partes, com demonstração de sua aplicabilidade no Brasil, ele também deverá ser tratado adequadamente na decisão mediante a análise de todos os elementos a serem aqui propostos, jamais aludido de maneira meramente superficial.

O dever de fundamentação adequada em face da invocação pelo advogado da parte não deixa de ser uma aplicação do art. 489, §1 ${ }^{\circ}$, do Código de Processo Civil, que dispõe quando uma decisão não é adequadamente fundamentada, especialmente incisos IV (não enfrentar todos os argumentos deduzidos no processo capazes de, em tese, infirmar a conclusão adotada pelo julgador); $\mathrm{V}$ (se limitar a invocar precedente ou enunciado de súmula, sem identificar seus fundamentos determinantes nem demonstrar que o caso sob julgamento se ajusta àqueles fundamentos) e VI (deixar de seguir enunciado de súmula, jurisprudência ou precedente invocado pela parte, sem demonstrar a existência de distinção no caso em julgamento ou a superação do entendimento).

Conquanto pareça um pouco mais evidente a exigência em razão do contraditório e da ampla defesa, inclusive em razão da citada disposição do Código de Processo Civil, é preciso detalhar um pouco mais o que seria essa obrigatoriedade em razão da integridade, concepção própria do interpretativismo de Ronald Dworkin ${ }^{14}$, ao propor que

14 DWORKIN, Ronald. O Império do Direito. São Paulo: Martins Fontes, 
quando um grupo social convive em uma comunidade de princípios, suas decisões, tanto legislativas quanto judiciais, devem buscar não somente um coerência, no sentido de manutenção estrita do mesmo entendimento observado em decisões anteriores, mas, sobretudo, um integridade, que é a observância aos princípios que unem e dão o tom de coesão àquela comunidade. A integridade, nesse contexto, é um ideal ao lado da justiça, da equidade e do devido processo legal.

Para explicar o Direito como integridade, Dworkin traça analogia com a integridade pessoal, de modo a evidenciar que uma pessoa íntegra pauta suas decisões nos diversos aspectos da vida segundo um mesmo grupo de princípios. Do mesmo modo deve agir uma comunidade política. Esse modelo, bem passa nos indispensáveis critérios de adequação (pois bem explica o comportamento dos juízes e legisladores) e do apelo moral (pois fornece um adequado parâmetro para decidir). Em outros termos, o Direito como integridade explica quando e por que juízes e legisladores seguem um padrão anterior ou quando rompem com ele de maneira justificável: seguem quando há uma convergência principiológica e divergem quando, no momento posterior, os mesmos princípios compartilhados pela comunidade política impõe o contrário. Essa é a prova do teste de adequação. A prova no teste do apelo moral coloca esse mesmo grupo de princípios como parâmetro decisório, especialmente em casos difíceis, em que não há uma resposta clara da ordem jurídica ou, em havendo, ela suscita graves questionamentos morais. Esse conjunto de princípios são inferidos das decisões de moralidade política da comunidade e servem justamente como parâmetro para decidir.

A comunidade de princípios e a integridade de Dworkin são claramente compreensíveis em uma comu-

1999. 
nidade jurídica que se organiza em um Estado, com uma constituição e um corpo de autoridades com poderes formais para tomar as decisões de moral política. Daí merecer uma maior explicação a exigência de integridade transnacional, o que, adiante-se, demanda que os países em questão compartilhem de elementos mínimos de moral política de modo a autorizar o transplante, e é justamente isso que os direitos humanos autorizam.

Essa é a proposta construída por Alonso Freire ${ }^{15} \mathrm{em}$ trabalho dedicado justamente ao tema da integridade transnacional dos direitos humanos. O autor propõe, com sucesso, diga-se logo, um parâmetro que se coloque intermediário entre o relativismo cultural e o universalismo dos direitos humanos.

O relativismo cultural, segundo o autor, "baseia-se no pressuposto de que os direitos humanos não podem ser apoiados em um fundamento moral universalmente reconhecido. Em outras palavras, não existe um único argumento ou justificativa para os direitos humanos capaz de ser aceito por todos e em todos os lugares". Por outro lado, a versão universalista é embasada em três premissas: a) pode e deve ser criada uma ordem normativa internacional para que se expressem normativamente decisões morais ligadas a todos os seres humanos; b) em havendo essa ordem moral global, ela deve ser juridicamente imposta; c) os direitos humanos podem ser explicados de maneira convergente por distintas bases filosóficas.

A proposta de Alonso Freire relaciona os pensamentos de Dworkin e Waldron, a despeito de ambos se filiarem a correntes teóricas plenamente distintas (Dworkin é o criador

15 FREIRE, Alonso. Integridade transnacional dos direitos humanos. Revista de Informação Legislativa. Brasília. Ano 53. N 209. Jan./mar. 2016. p. 255-275. 
do interpretativismo, enquanto Waldron é descrito como um positivista normativo). De Dwrokin retira a noção de integridade já exposta acima. De Waldron retira a ideias de leis parcialmente comum a toda espécie humana, a figuração das cortes internacionais como laboratórios de direitos humanos e o tratamento igualitário transnacional. Embora Alonso Freire não diga expressamente, são essas ideias que permitem pressupor a comunidade de princípio que autoriza a exigência do ideal de integridade. É justamente a existência ou não de um compartilhamento principiológico que explica, por exemplo, porque é adequado invocar precedente da Corte Constitucional da Colômbia, e não é adequado invocar decisões de países do oriente médio em que a religião islâmica não é separada dos assuntos do Estado.

Ao invocar Waldron para se colocar em uma terceira opção entre o universalismo e o relativismo, Alonso Freire acredita que "os direitos humanos e os precedentes estrangeiros e internacionais a respeito deles podem formar um corpo de leis que poderíamos chamar de direitos das nações. Ou seja, também defender a ideia de que todos os povos que são regidos por leis e costumes usam parcialmente suas próprias leis e leis parcialmente comuns a toda espécie humana".

Assim, não basta o advogado aludir retoricamente a um precedente estrangeiro para criar a obrigação de o juiz ou tribunal se manifestarem, ele tem que fazer o adequado uso, que pressupõe, antes de mais nada, uma demonstração de que o tribunal estrangeiro emissor da decisão faz parte de um país que, de algum modo, compartilhe os mesmos princípios de direitos humanos que o Brasil pratica. Em igual sentido, mesmo não citado pelos advogados das partes, um juiz ou tribunal deve se sentir principiologicamente obrigado a considerar a decisão de tribunais estrangeiros que tenham enfrentado casos envolvendo os mesmos princípios relacionados aos direitos humanos de que compartilhem com 
o Brasil. E isso é necessário justamente porque os tribunais estrangeiros devem ser considerados laboratórios de direitos humanos em uma comunidade internacional em torno dos mesmos. Explica-se com mais detalhe.

Para Waldron, o uso de precedentes estrangeiros deve ser compreendido de maneira similar a um cientista em face da comunidade científica mundial. Um cientista realizando uma pesquisa em seu país de origem não o pode ignorar o conhecimento produzido por outros estudiosos em outros países e que esteja compartilhado internacionalmente, sob pena de incorrer em um trabalho com maiores probabilidades de fracasso, por se manter surdo, ou mesmo não obter validação de suas propostas por diferir dos padrões de cientificidade mundialmente aceitos. Similarmente, um tribunal local, decidindo um caso que envolva princípios compartilhados transnacionalmente, não pode ignorar o que outras cortes que o compartilhem tenham decidido a seu respeito, correndo o risco de proferir decisão mais frágil e criticável, justamente por quem possa invocar os padrões estrangeiros e mesmo, com base neles, buscar um backlash.

Isso não significa que se deva realizar importações acríticas. Quando se menciona considerar, envolve a possibilidade de analisar o precedente para, se for o caso, deixar de aplicá-lo, desde que fundamentadamente. Trata-se de uma atitude muito mais segura do que simplesmente silenciar. É o que expõe Alonso Freire, ao afirmar: "mesmo que juízes e juristas reconheçam que aspectos culturais ou políticos de seus sistemas devam ser levados em consideração ao analisarem os casos que devem julgar, seria insensato que desconsiderassem ou resistissem a investigar se há alguma espécie de consenso jurídico sobre o caso em questão".

O autor, ainda na esteira de Waldron, indica, como razão adicional para observar precedente estrangeiro, o dever de tratar casos iguais igualmente. No entanto, entende-se, 
aqui, que não há um dever de tratamento isonômico transnacionalmente, exaurindo-se a convergência necessária na ideia de integridade, conforme exposto.

Esses são os dois parâmetros, portanto, que permitem e mesmo exigem a observância de um precedente estrangeiro: razões de integridade e razões de integridade somadas à imposição do contraditório e da ampla defesa.

Uma vez postos os casos em que se podem e quando se devem observar os precedentes alienígenas, busca-se, então, qual a maneira adequada de fazê-lo. Em vislumbre disso, Mark Tushnet ${ }^{16}$, consoante exposto mais acima, apresenta três formas: funcionalismo, expressivismo e bricolagem.

Segundo o funcionalismo, um instituto estrangeiro deve ser compreendido em razão do papel que desempenha no direito estrangeiro, suas repercussões e interações. Tem como ponto frágil, a impossibilidade de um estrangeiro apreender todo esse aspecto funcional daquilo que importa.

Quanto ao expressivismo, aponta que, em se tratando de direito constitucional, o que pode ser estendido aos direitos humanos, cada instituto é a expressão da sociedade em que é adotada. Por exemplo, as disposições constitucionais alemãs só podem ser compreendidas adequadamente em função de sua culpa histórica de ter adotado o nazismo, o que não pode ser inteiramente apreendido por outras sociedades.

Por fim, Tushnet propõe a bricolagem com base em lições de Levy-Strauss, que contrapõe esse método àqueles típicos de projetos da engenharia, por exemplo, em que se tem um modelo completo a ser seguido e no qual são identificados previamente os materiais disponíveis a serem trabalhados. Um projeto de engenharia reúne e concebe, portanto, ferramentas para usar o material e executar o projeto com a

16 TUSHNET, Mark. The Possibilities of Comparative Constitutional Law. 108 Yale Law Journal. 1225 (1999) 
visão do todo. Na bricolagem, por outro lado, não há essa previsão completa, nem a visão do todo ou a seleção prévia e plena das ferramentas. Trabalha-se com o disponível e que esteja à mão. As colocações ficam mais claras quando Tushnet aplica a ideia para o direito constitucional:

We can apply that insight to constitution-making and interpretation as well. I begin by using the idea of bricolage to explore some difficulties with a particular strategy for interpreting the Constitution, which links a highly rationalized textualism to some form of originalism. The argument starts with the modest suggestion that some constitutional provisions should be understood to result from compromises that rest on no single coherent principle. Invoking the idea of bricolage, however, it broadens that suggestion into a far more general perspective on interpretation that brings into question first the idea that the Constitution is the result of rational deliberation, including rational compromises, and then the idea that interpretation is something other than the transformation and coopting of the legal materials that the interpreter's culture makes available. I follow by briefly discussing the way in which functionalism and expressivism may limit the possibility of appropriating something that might seem to be "a hand" and conclude by suggesting that, nonetheless, recent interest in comparative constitutional law shows how experience elsewhere has become available to U.S. constitutionalists who now find themselves participants in a world-wide legal culture.

Alonso Freire, em seu artigo "Importação de Ideias Constitucionais", aduz que toda importação de ideias por meio da utilização de precedentes de Cortes estrangeiras deve ser previamente justificada. A referida justificação deve ocorrer tanto de forma abstrata quanto de forma concreta.

A justificação em abstrato deve conter os elementos de racionalidade e legitimidade. $\mathrm{O}$ problema da racionalidade consiste em determinar se é possível ou não fazer um uso racional e controlado da ideia constitucional que se quer importar. A legitimidade, por sua vez, envolve a discussão 
se os tribunais que pretendem fazer uso dessas ideias estão autorizados a aplicá-las, considerando os princípios basilares da ordem constitucional do país importador. A justificação em concreto, por sua vez, diz respeito à necessidade da utilização da ideia constitucional no sistema jurídico de destino ${ }^{17}$.

Entende-se, no entanto, que cada uma dessas propostas isoladas peca por dar ênfase a apenas um dos aspectos possíveis, pelo que se propõe a substituição por uma perspectiva hermenêutica, que busca compreender todos esses aspectos que integram o sentido do precedente que se quer observar. E é esse ganho hermenêutico no tribunal de origem que deve ser buscado para se reproduzir no Brasil.

Assim, é possível destacar elementos materiais que compõem e identificam esse ganho hermenêutico e sua força materialmente vinculante por ocasião da aplicação, são eles: a) sua integridade, no sentido de estar embasado em princípios comuns; b) coerência, em que se examina a convergência estrita do precedente com outras fontes jurídicas do país de aplicação, assim como as repercussões do precedente no pais de origem e sua incorporação ou não por lá; c) fundamentação, consistente na exposição e justificação da solução adotada, sobretudo por ser o dado que permite a compreensão de todo o labor hermenêutico realizado na origem. Tais elementos não deixam de ser a adaptação de elementos já propostos para uso de precedentes nacionais ${ }^{18}$.

Nessa linha, o uso adequado de precedente estrangeiro, envolve inicialmente a demonstração de integridade, indicando que o país do tribunal de origem partilha aspectos

17 FREIRE, Alonso. Importação de ideias constitucionais. 2015. Disponível em: <http://www.osconstitucionalistas.com.br/importacao-de-ideias-constitucionais>. Acesso em: 03 dez. 2017.

18 LOPES FILHO, Juraci Mourão. Os precedentes judiciais no constitucionalismo brasileiro contemporâneo. 2.ed. Salvador: Juspodivm, 2016. 
culturais, sociais e políticos similares aos do Brasil (o que pode ser comprovado, por exemplo, pela existência de tratados ou convenções de direitos humanos que ambos sejam signatários), a fim de evidenciar que comungam princípios, que orientem tanto o tribunal alienígena quanto o nacional. Também envolve a observância da coerência do precedente tanto na origem quanto com outras decisões e normas brasileiras, assim como a justificação da decisão base do precedente estrangeiro.

No concernente à coerência, deve ser considerado: a) a existência de desafios ou reforços ao precedente, seja no aspecto doutrinários ou de outras fontes do direito, ou se ele gerou jurisprudência, e, se gerou, como foi a evolução do que foi decidido inicialmente; b) similitude hermenêutica das questões enfrentadas no estrangeiro com a realidade brasileira; c) existência de modificação legislativa ou constitucional no país de origem que reforcem ou enfraqueçam o precedente então firmado; d) manutenção ou alteração do quadro político, social ou cultura que de uma maneira geral seria partilhada entre os dois países.

Com relação à justificação, é preciso investigar no precedente estrangeiro: a) a existência de uma fundamentação adequada e detida de todos os aspetos pertinentes, inclusive se há enfrentamento de questões similares das encontradas e postas no caso brasileiro; b) a qualidade dessas análises, percorrendo um arco completo de análise.

São esses, portanto, os elementos substanciais que devem ser considerados na invocação de precedente estrangeiro e que determinam sua força hermenêutica para solução de questão similar no Brasil. 


\section{ANÁLISE DA AÇÃO DE DESCUMPRIMENTO DE PRECEITO FUNDAMENTAL (ADPF) №347.}

O tema do Estado de Coisas Inconstitucional chegou ao Supremo por meio da mencionada ADPF $n^{\circ} 347$, de relatoria do Ministro Marco Aurélio. A referida ação foi proposta pelo Partido Socialismo e Liberdade - PSOL, tendo como advogado o ilustre constitucionalista Daniel Sarmento, em que pleiteou, expressamente, a declaração de um Estado de Coisas Inconstitucionais, a qual deveria ser seguida pela adoção de providências estruturais em face de lesões aos preceitos fundamentais dos detentos.

Argumentou-se que com a declaração do ECI, o Supremo poderia compelir os Poderes Políticos - Executivo e Legislativo - a tomarem medidas emergenciais para a superação do cenário caótico existente nas penitenciárias brasileiras. Alegou-se, ainda, que a intervenção direta do judiciário no controle da política pública não ofenderia a separação de poderes, uma vez que tal intervenção só poderia ocorrer em casos excepcionais, voltando-se a defesa de uma minoria impopular, que não apresenta representação política suficiente para que a Administração, por si só, faça investimentos em políticas que objetivem a melhoria de sua qualidade de vida ${ }^{19}$.

O quadro comparativo traçado entre a situação colombiana e brasileira é apto a demonstrar a validade de importação do precedente estrangeiro, pois demonstra não só similaridades fáticas, sociológicas e culturais, mas também um compartilhamento principiológico, demonstrado mesmo por tratados internacionais firmados por ambos os países,

19 CAMPOS, Carlos Alexandre de Azevedo. Estado de Coisas Inconstitucional. Salvador: Juspodium, 2016, p. 286. 
indispensável, como visto, para que o julgado tenha valor hermenêutico aqui.

Frisa-se que o mérito da ADPF n 347 ainda não foi julgado, tendo o ECI sido declarado em decisão acerca dos pedidos cautelares. Foram formulados oito pedidos cautelares: 1) determinação a juízes e tribunais de motivarem expressamente nos casos de decretação ou manutenção de prisão provisória, o porquê de não aplicarem medidas cautelares alternativas; 2) aplicação dos artigos 9.3 do Pacto dos Direitos Civis e Políticos e 7.5 da Convenção Interamericana de Direitos Humanos; 3) determinação aos juízes e Tribunais para que passem a considerar o quadro do sistema penitenciário no momento de concessão de cautelares penais, na aplicação de pena e durante o processo de execução penal; 4) a observância, quando possível a penas alternativas à prisão; 5) seja determinado ao juiz da execução penal o abrandamento dos requisitos temporais para a fruição de benefícios e direitos dos presos quando evidenciado que o cumprimento da pena se deu em condições mais severas que as previstas na ordem jurídica; 6) abatimento do tempo de execução da pena se restar verificado que as condições de cumprimento da pena foram mais severas que as previstas na ordem jurídica, como forma de compensação; 7) determinação ao Conselho Nacional de Justiça $(\mathrm{CNJ})$ para coordenar a realização de um mutirão carcerário, a fim de revisar todos os processos de execução penal em curso no país; 8) o imediato descontigenciamento de verbas do Fundo Penitenciário Nacional (FUNPEN) e a que a União se abstenha de realizar novas reservas de contenção ${ }^{20}$.

Diante de tais pedidos, a medida cautelar foi parcialmente deferida, restando consignado que os juízes e Tribu-

20 CAMPOS, Carlos Alexandre de Azevedo. Estado de Coisas Inconstitucional. Salvador: Juspodium, 2016, p. 286/287. 
nais devem observar aos artigos 9.3 do Pacto dos Direitos Civis e Políticos ${ }^{21}$ e 7.5 da Convenção Interamericana de Direitos Humanos ${ }^{22}$; que as audiências de custódia fossem realizadas em até 90 (noventa) dias em todo o território nacional, viabilizando o comparecimento do preso perante a autoridade judiciária no prazo máximo de 24 horas, contadas do momento do recolhimento, e que a União liberasse toda a verba contingenciada do Fundo Penitenciário Nacional (FUNPEN), abstendo-se de realizar novas contenções.

Os ministros Luís Roberto Barroso, Edson Fachin, Rosa Weber, Luiz Fux, Carmen Lúcia, Celso de Mello e Ricardo Lewandowski reconheceram textualmente em seus votos a existência de um Estado de Coisas Inconstitucionais no sistema penitenciário brasileiro. Não se observa nos votos, entretanto, qualquer limitação aos contornos jurídicos e fáticos para a sua declaração.

O Ministro Marco Aurélio afirma em seu voto que a utilização do ECI deve ocorrer apenas em contextos excepcionais, de modo que os direitos à saúde, educação e transporte,

21 Qualquer pessoa presa ou encarcerada em virtude de infração penal deverá ser conduzida, sem demora, à presença do juiz ou de outra autoridade habilitada por lei a exercer funções judiciais e terá o direito de ser julgada em prazo razoável ou de ser posta em liberdade. A prisão preventiva de pessoas que aguardam julgamento não deverá constituir a regra geral, mas a soltura poderá estar condicionada a garantias que assegurem o comparecimento da pessoa em questão à audiência, a todos os atos do processo e, se necessário for, para a execução da sentença. (BRASIL. Decreto $n^{0}$ 595, de 06 de julho de 1992. Atos Internacionais. Pacto Internacional sobre Direitos Civis e Políticos. Promulgação. Decreto. Nova York).

22 Toda pessoa detida ou retida deve ser conduzida, sem demora, à presença de um juiz ou outra autoridade autorizada pela lei a exercer funções judiciais e tem direito a ser julgada dentro de um prazo razoável ou a ser posta em liberdade, sem prejuízo de que prossiga o processo. Sua liberdade pode ser condicionada a garantias que assegurem o seu comparecimento em juízo. (BRASIL. Decreto nº 678, de 06 de novembro de 1992. Promulga a Convenção Americana sobre Direitos Humanos (Pacto de São José da Costa Rica). Decreto. Brasília, DF). 
por exemplo, não podem ter sua prestação melhorada mediante a declaração de um Estado de Coisas Inconstitucional, uma vez que para tais direitos há disposição política e social.

Ante os pressupostos formulados pela Corte Constitucional da Colômbia para apontar a configuração do "estado de coisas inconstitucional", não seria possível indicar, com segurança, entre os muitos problemas de direitos enfrentados no Brasil, como saneamento básico, saúde pública, violência urbana, todos que se encaixariam nesse conceito. Todavia, as dificuldades em se definir o alcance maior do termo não impedem, tendo em conta o quadro relatado, seja consignada uma zona de certeza positiva: o sistema carcerário brasileiro enquadra-se na denominação de "estado de coisas inconstitucional ${ }^{23}$.

Marco Aurélio ${ }^{24}$ afirma ainda que:

O requerente diz estar configurado o denominado, pela Corte Constitucional da Colômbia, de "estado de coisas inconstitucional". Segundo as decisões desse Tribunal, há três pressupostos principais: situação de violação generalizada de direitos fundamentais; inércia ou incapacidade reiterada e persistente das autoridades públicas em modificar a situação; a superação das transgressões exigir a atuação não apenas de um órgão, e sim de uma pluralidade de autoridades.

Observa-se, portanto, que o relator não discutiu as dimensões do instituto acolhido, limitando-se a transcrever passagem da exordial, sem indicar se o Judiciário brasileiro está acolhendo os pressupostos utilizados na Colômbia para a configuração do ECI, tampouco discutiu os pressupostos ligados a coerência da invocação do precedente, tais como: por quanto tempo a conduta omissiva dos poderes políticos deve ser verificada para que haja configuração do ECI? Ou

23 BRASIL. Supremo Tribunal Federal. ADPF No 347. Relator: Marco Aurélio. Brasília, DF de 2015. Diário Oficial da União. Brasília, 2015. p. 30.

24 BRASIL. Supremo Tribunal Federal. ADPF No 347. Relator: Marco Aurélio. Brasília, DF de 2015. Diário Oficial da União. Brasília, 2015. p. 30. 
ainda, a política de saúde, por exemplo, não obstante tenha maior interesse político e social na sua efetivação, contempla esferas de baixo interesse político, como quebra de patentes, assim, esses outros aspectos de baixo interesse político poderiam ter sua efetivação aprimorada mediante a declaração do ECI, ainda que constituam elementos de uma política profundamente regulamentada?

Percebe-se, também, a falta de discussão acerca do papel a ser assumido pelo Judiciário após a declaração do ECI: se emitirá comandos de intervenção direta na política pública deficiente ou se apenas homologará eventuais planos de ação propostos pelo Executivo e pelo Legislativo. Além disso, não se debateu como ocorrerá a fiscalização do cumprimento da ADPF $n^{\circ} 347$.

Nesses tocantes, a jurisprudência colombiana poderia ter sido mais explorada, no concernente a todo o espectro decisório próprio da integridade e coerência. Conquanto se tenha invocado julgado que tinha uma fundamentação devida, não se observaram esses outros dois aspectos substanciais. Houvesse sido realizada a adequada importação dos precedentes estrangeiros, ter-se-ia percebido que, na Colômbia, não existiu um único modelo de ECI, e que as consequências de opções similares à adotada no Brasil levaram ao fracasso, precisamente no tocante à situação da população carcerária.

Carlos Alexandre de Azevedo Campos fala da existência de ciclos desse instituto, os quais foram ignoradas no julgamento da medida cautelar pelo Supremo Tribunal Federal. Existiram duas fases no país de origem. A primeira com início em 1997 até 2003, em que a Corte Constitucional Colombiana (CCC) declarou a existência de um Estado de Coisas Inconstitucional sobre situações em que não se faziam presente falhas estruturais e de violação massiva de direitos, 
o que gerou um enfraquecimento do instituto, bem como sua inefetividade, ocasionado pela ausência de implantação de mecanismos de fiscalização da decisão judicial. Nessa fase, identificam-se os piores erros acerca da implantação do ECI: falta de rigor na identificação de seus pressupostos e critérios, além da baixa efetividade ${ }^{25}$.

A segunda fase do ECI na Colômbia, iniciada em 2004, com a decisão T-025, foi marcada por um período de maior eficácia do instituto, uma vez que a Corte definiu mecanismos expressos de fiscalização das decisões, garantindo seu cumprimento, além de ter compilado critérios para verificar a existência de um Estado de Coisas Inconstitucional, evitando sua banalização.

Referente à segunda fase do Estado de Coisas Inconstitucional, Roman Corredor afirma que a Corte Constitucional Colombiana analisa dez critérios para definir se deve ou não haver a declaração do ECI sobre certa situação;

A) Inobservância reiterada e geral das liberdades e direitos essenciais pelos poderes públicos. B) Adoção de práticas constitucionais por ditos poderes. C) A omissão dos órgãos competentes em matéria de defesa de direitos constitucionais em adotar as medidas corretivas a violações desses direitos. D) A manutenção de normativas transitórias e provisionais em matéria de direitos fundamentais, como o da autonomia e independência do poder judicial e seu regime disciplinar. E) $\mathrm{O}$ ativismo judicial. F) A temporariedade de juízes. G) $\mathrm{O}$ funcionamento deficiente e o desempenho insuficiente dos organismos judiciais e de defesa e proteção dos direitos fundamentais. $\mathrm{H}$ ) O exercício de delegação legislativa ilimitada pelo poder executivo. I) A impunidade em delitos de corrupção e contra os direitos humanos. E, J) A substituição dos mecanismos formais de reforma constitucional e do poder constituinte pela justiça constitucional ${ }^{26}$.

25 CAMPOS, Carlos Alexandre de Azevedo. Estado de Coisas Inconstitucional. Salvador: Juspodium, 2016, p. 167.

26 CORREDOR, Róman J. Duque. Estado de Derecho y justicia: desvia- 
No Brasil, entretanto, a discussão acerca do conceito de Estado de Coisas Inconstitucional não perpassou nenhum dos votos dos Ministros, ou seja, invocou-se um precedente estrangeiro e aplicou-se um instituto sem se perquirir todos os aspectos hermenêuticos pertinentes nem se analisar todo o arco jurisprudencial em busca de uma coerência ampla na origem, sem sequer definir suas dimensões, o que constitui um forte entrave para maior eficácia da decisão cautelar justamente porque não espelhadas, no Brasil, as particularidades da jurisprudência estrangeira.

Aparentemente, importou-se a versão inicial do ECI desenvolvido na Colômbia, em que os critérios determinantes para a declaração de existência de um Estado de Coisas Inconstitucional eram imprecisos e difusos, carente de univocidade, que acarretou, por isso, falta de concretude e de segurança jurídica das decisões que declararam a existência de um ECI, bem como falta de segurança jurídica. Afinal, se os critérios não são bem delineados, então a utilização do instituto fica ao alvedrio da Corte Constitucional ${ }^{27}$. Não se observou, como já expresso, todo o arco jurisprudencial de desenvolvimento, não se consideraram os desafios e reforços ocorridos após o primeiro julgamento. Considerou-se apenas a similitude fática e principiológica entre o primeiro precedente colombiano e o caso levado pelo PSOL, pouco se observou a respeito da coerência e interação sistêmica posterior.

Percebe-se, portanto, que o Supremo não realizou de forma precisa a discussão acerca do tema, importando a ver-

ciones y manipulaciones. El Estado de cosas inconstitucional, Provincia Especial, 2006, p. 343-344

27 CÁRDENAS, Blanca Raquel. Contornos jurídico-fácticos del Estado de Cosas Inconstitucional. Colombia: U. Externado de Colombia,, 2011. p. 20. 
são mais arcaica do instituto e sem discutir a compatibilidade desse com o ordenamento jurídico brasileiro.

Percebe-se, assim, que o Supremo procurou imputar os problemas da política penitenciária exclusivamente a decisões do Executivo, buscando retirar o enfoque do Poder Judiciário. Tal poder, entretanto, possui, também, responsabilidade no delineamento da condição penitenciária, sobretudo se considerar-se que a população carcerária brasileira é a quarta maior do mundo com 622.202 mil encarcerados, perdendo apenas para Estados Unidos, China e Rússia e nos últimos 14 anos a população do sistema prisional brasileiro teve um aumento de $167,32 \%$, muito acima, portanto, do crescimento demográfico, aumento que reflete a existência de uma política criminal encarceradora ${ }^{28}$.

Dessa maneira, a solução do problema penitenciário não está no simples aumento do número de vagas, mas, "no envolvimento dos três Poderes da República, em todos os níveis da Federação, além de se relacionar diretamente com o que a sociedade espera do Estado como ator de pacificação social $^{29 \prime \prime}$.

Como afirma Carolina Haber, a superação desse quadro de violação massiva e estrutural dos direitos dos presidiários depende que os três poderes atuem de forma conjunta. Ações isoladas acabam por criar um problema conjunto ${ }^{30}$.

28 BRASIL. MINISTÉRIO DA JUSTIÇA. DEPEN - Departamento Penitenciário Nacional. Levantamento nacional de informações penitenciárias - INFOPEN. Brasília: Ministério da Justiça - DEPEN, junho de 2014, p. 06 e 14.

29 BRASIL. MINISTÉRIO DA JUSTIÇA. DEPEN - Departamento Penitenciário Nacional. Levantamento nacional de informações penitenciárias - INFOPEN. Brasília: Ministério da Justiça - DEPEN, junho de 2014, p. 16.

30 HABER, Carolina. Protagonismo do Supremo na política carcerária: necessário, mas insuficiente. In: FALCÃO, Joaquim; ARGUELHES, Diego Werneck; RECONDO, Felipe. Onze Supremos: O Supremo em 2016. Belo Horizonte: Fgv, 2017. p. 209. 
Assim, a possível solução ao sistema penitenciário está em uma atuação conjunta, sistêmica e interinstitucional entre todas as esferas de governo, perpassando, inclusive, por uma modificação na atuação do Poder Judiciário, o qual deverá apresentar maior compromisso na fundamentação das decisões que culminem na prisão. Defende-se, portanto, que tais decisões devam apresentar maior ônus argumentativo para justificar a não aplicação de uma medida alternativa.

Nesse sentido, a declaração de um Estado de Coisas Inconstitucional por um Judiciário que se negou a assumir compromisso de motivar mais profundamente e com maior qualidade as decisões que culminassem na realização de prisões, além de não ter realizado qualquer discussão acerca da implantação de cursos de formação ou outras estratégias para rever a mentalidade encarceradora que domina os juízes brasileiro, pouco contribuirá para a modificação do quadro de superlotação penitenciária. Transferiu, simplesmente, todo o problema para os poderes políticos, como se a solução estivesse apenas na liberação de mais recursos para o financiamento da política penitenciária, quando, em verdade, a questão passa igualmente pela modificação na atuação do próprio Judiciário.

Desse modo, além da falta de conceituação do que, de fato, seria o Estado de Coisas Inconstitucional e quais os seus limites, há, ainda, outros entraves para a utilização da ADPF $n^{\circ} 347$ enquanto precedente interno para orientar decisões futuras, conforme se passa a analisar. 


\section{ENTRAVES PARA UMA FUNDAMENTAÇÃO BASEADA NO ESTADO DE COISAS INSTI- TUCIONAIS: O SIMBOLISMO DA DECISÃO CAUTELAR DA ADPF N 347.}

A decisão cautelar proferida na ADPF n 347 apresenta uma série de incongruências argumentativas que dificultam a sua utilização enquanto precedente. Inicialmente, cumpre esclarecer que, na Colômbia, o controle abstrato de constitucionalidade encontra-se previsto nos artigos 241, parágrafo $1^{\mathrm{o}}$ e $4^{\mathrm{o} 31}$, e art. 242, parágrafo $1^{\mathrm{o32}}$, ambos da Constituição. Percebe-se que o texto prevê a possibilidade de controle abstrato, entretanto não faz menção aos seus efeitos. Dessa forma, o Estado de Coisas Inconstitucional é desenvolvida pela Corte Constitucional Colombiana, em verdade, como

31 Artículo 241. A la Corte Constitucional se le confía la guarda de la integridad y supremacía de la Constitución, en los estrictos y precisos términos de este artículo. Con tal fin, cumplirá las siguientes funciones: 1. Decidir sobre las demandas de inconstitucionalidad que promuevan los ciudadanos contra lós actos reformatorios de la Constitución, cualquiera que sea su origen, solo por vicios de procedimiento en su formación. 4. Decidir sobre las demandas de inconstitucionalidad que presenten los ciudadanos contra las leyes, tanto por su contenido material como por vicios de procedimiento en su formación. (COLOMBIA. Gov. Constitución Política de Colombia. Disponível em:<http://www.corteconstitucional.gov.co/inicio/Constitucion\%20politica\%20de\%20Colombia\%20-\%202015.pdf $>$. Acesso em: 03 dez. 2017).

32 Artículo 242. Los procesos que se adelanten ante la Corte Constitucional en las materias a que se refiere este título, serán regulados por la ley conforme a las siguientes disposiciones: 1. Cualquier ciudadano podrá ejercer las acciones públicas previstas en el artículo precedente, e intervenir como impugnador o defensor de las normas sometidas a control en los procesos promovidos por otros, así como en aquellos para los cuales no existe acción pública. (COLOMBIA. Gov. Constitución Política de Colombia.Disponívelem: $<$ http://www.corteconstitucional.gov.co/inicio/Constitucion\%20politica\%20de\%20Colombia\%20-\%202015.pdf>. Acesso em: 03 dez. 2017). 
tentativa de garantir efeito transcendente e vinculante à decisão judicial. Tal problema de ordem processual não é verificado no Brasil, uma vez que se dispõe de mecanismos de controle concentrado, como a própria ADPF, que já apresentam essas ferramentas ${ }^{33}$.

Assim, o ECI na Colômbia surge em uma perspectiva completamente distinta daquela que resultou em sua importação para o Brasil. Na Colômbia, o controle abstrato não possui os efeitos de generalidade que já dispomos e, por isso, o desenvolvimento da teoria do ECI nesse país ocorre em razão da absorção da noção de structural litigation, originalmente desenvolvida nos Estados Unidos.

A structural litigation é equivalente à expressão public law litigation e se diferencia da private litigation. Na structural litigation, as pessoas diretamente relacionadas ao tema judicializado são amorfas e difusas, bem como o tipo de intervenção que se requer do Judiciário é mais complexo ${ }^{34}$. Daí a necessidade da decisão judicial produzir efeitos erga omnes.

No Brasil, por sua vez, a importação do Estado de Coisas Inconstitucional ocorreu diante da ausência de mecanismos de controle de constitucionalidade sobre omissões inconstitucionais não normativas. Esse tipo de inconstitucionalidade não é caracterizado pela falta de regulamentação da política pública pelo Legislativo, mas se distingue por falhas de coordenação entre o Legislativo e o Executivo, circunstância que implica deficiências na consecução de políticas

33 PEREIRA, Jane Reis Gonçalves; GONÇALVES, Gabriel Accioly. Inconstitucionalidade sistêmica e multidimensional: transformações no diagnóstico das violações à Constituição. Juris Poiesis, Rio de Janeiro, v. 18, p.130-159, jan. 2015. Anual, p. 148.

34 V. NEFF, Emma C. From Equal Protection to the Right to Health: Social and Economic Rights, Public Law Litigation, and How an Old Framework Informs a New Generation of Advocacy, Columbia Journal of Law and Social Problems, v. 43, n. 2, 2009, p. 158-159 
públicas e na efetivação dos direitos fundamentais sociais, inviabilizando o completo e integral desenvolvimento humano da sociedade.

Por esse motivo, o sentido de incorporar o Estado de Coisas Inconstitucional ao Brasil está na tentativa de injetar valores constitucionais na sociedade e no próprio Estado, buscando reverter práticas, costumes ou estados já sedimentados e que são incompatíveis com a Constituição ${ }^{35}$.

Pelo exposto, percebe-se que o Supremo não realizou distinção entre as razões que levaram ao surgimento do Estado de Coisas Inconstitucionais na Colômbia e as razões que culminaram na importação desse instituto para o Brasil, argumentação que deveria estar contida nos votos, uma vez que as situações de surgimento do ECI nos referidos países são completamente distintas. Falhou-se, nesse ponto, na análise do contexto normativo.

Ao realizar a importação do ECI, o STF, além de não ter discutido qual seria seu conteúdo, deveria tratar acerca do impacto da importação dessa ideia sobre a identidade constitucional do país importador. Afinal, deve-se discutir se o elemento importado não causará danos à identidade da Constituição ${ }^{36}$.

A decisão cautelar da ADPF n 347 deveria ter respondido, portanto, aos seguintes questionamentos: É possível a utilização racional do Estado de Coisas Inconstitucional no Brasil? O Supremo Tribunal Federal tem legitimidade para reconhecer o ECI e para tomar medidas estruturais? Há realmente necessidade de utilização dessa ideia em nosso sistema jurídico, considerando a existência de ações de controle concentrado de constitucionalidade com os moldes

35 FISS, Owen M. Foreword: The Forms of Justice, Harvard Law Review, v. 93, n. 1, 1979, p. 4.

36 JACOBSOHN, Gary Jeffrey. Constitutional Identity. Cambridge, Mass.: Harvard University Press, 2010, p. 181 
prescritos? Como exercer controle de constitucionalidade sobre a realidade empírica, considerando que esse instituto foi desenvolvido para ser realizado sobre normas ${ }^{37}$ ?

Além da falta de motivação acerca dessas questões, há ainda outros pontos que não foram devidamente observados pela decisão analisada, como: em momento algum se desenvolveu argumentação acerca da compatibilidade do Estado de Coisas Inconstitucional com o princípio da separação dos poderes, analisando se essa determinação do Poder Judiciário influenciando diretamente na execução da política pública trata-se ou não, de uma ponderação entre o princípio da separação de poderes e os outros que necessitam ser resguardados, com todo o ônus argumentativo que advém de flexibilizar tão caro princípio democrático. Ou, caso entendesse que não há violação há separação de poderes, isso deveria ser tornado explícito, com os argumentos pertinentes, de modo a delinear o conceito dos limites da separação de poderes adotado pelo tribunal superior nesse julgamento.

Outra questão que deveria ter sido alvo de argumentação nos votos é se as medidas cautelares deferidas pelo Supremo são adequadas, necessárias e proporcionais para a concretização do bem que se espera, qual seja, a reversão do quadro de ECI do sistema penitenciário brasileiro? Quais provas foram analisadas para justificar a adoção daqueles meios como eficientes para a obtenção do fim desejado? Como o descontigenciamento de verbas do FUNPEN e a realização das audiências de custódia são medidas suficientes e necessárias para a superação do quadro de violação massiva e estrutural dos direitos fundamentais dos presidiários?

37 STRECK, Lenio Luiz. Estado de Coisas Inconstitucional é uma nova forma de ativismo. 2015. Disponível em: <https://www.conjur.com. br/2015-out-24/observatorio-constitucional-estado-coisas-inconstitucional-forma-ativismo>. Acesso em: 03 dez. 2017. 
No que concerne aos aspectos formais para definição da força hermenêutica do precedente (nível hierárquico da Corte emissora da decisão e tipo de processo em que se emitiu o precedente ${ }^{38}$ ), é claro que a medida cautelar proferida apresenta grau máximo de força, sobretudo se levarmos em conta o teor do art. 927, I, do Código de Processo Civil, em que resta consignado que as decisões do Supremo Tribunal Federal em controle concentrado de constitucionalidade devem ser observadas.

Quando, entretanto, realiza-se a análise dos aspectos materiais para a fixação da força hermenêutica do precedente, tem-se que a decisão cautelar da ADPF $n^{\circ} 347$ apresenta baixo poder de influência sobre casos futuros, uma vez que a referida decisão não apresentou fundamentação adequada e detida acerca do caso, por todos os vácuos argumentativos acerca das questões arguidas nesse tópico ${ }^{39}$.

$\mathrm{O}$ aspecto argumentativo da decisão em análise restou tão aquém do esperado que há inclusive dificuldade na identificação da sua ratio decidendi. A ratio corresponde aos fundamentos ou teses jurídicas que permitem ao magistrado, ao analisar o caso concreto, à luz do direito, tomar certa decisão, a qual poderá influenciar decisões judiciais futuras ${ }^{40}$.

No caso em análise pode-se dizer que a ratio decidendi está em reconhecer a existência de um Estado de Coisas Inconstitucional no sistema penitenciário brasileiro, premissa

38 LOPES FILHO, Juraci Mourão. Os precedentes judiciais no constitucionalismo brasileiro contemporâneo. 2. ed. Salvador: Juspodium, 2016, p. 420.

39 LOPES FILHO, Juraci Mourão. Os precedentes judiciais no constitucionalismo brasileiro contemporâneo. 2. ed. Salvador: Juspodium, 2016, p. 427.

40 DIDIER JR., Fredie. BRAGA, Paula Sarno; OLIVEIRA, Rafael Alexandria de. Curso de Direito Processual Civil: teoria da prova, direito probatório, ações probatórias, decisão, precedente, coisa julgada e antecipação dos efeitos da tutela. Salvador: JusPODIVM, 2015, v. 2, p. 443. 
sobre a qual houve consenso de todos os Ministros, e que para superar essa questão, o imediato descontigenciamento de verbas do FUNPEN e a realização de audiências de custódia seriam mecanismos eficientes, disposições não dotadas de consenso.

Não se sabe, sequer, o que se entende por Estado de Coisas Inconstitucional no Brasil. Diante disso, como defender a observância obrigatória dessa decisão, como prescreve o Código de Processo Civil, se não se sabe sequer o que foi de fato decidido?

No que concerne as divergências existentes quanto à decisão acerca da realização das audiências de custódia e liberação de verbas do FUNPEN, tem-se que esses aspectos também contribuem para o enfraquecimento da força hermenêutica da decisão, uma vez que as decisões tomadas não demonstram a opinião da Corte, mas sim a opinião de cada Ministro de forma isolada, o que inviabiliza a utilização de tal de decisão enquanto precedente.

Virgílio Afonso da Silva explicita que, "eles [o STF e os demais tribunais superiores] não decidem como instituição, eles decidem com os argumentos dos seus ministros, é uma soma de opiniões; o Supremo não vota como instituição ${ }^{41}{ }^{\prime \prime}$.

Observa-se que a Ministra Rosa Weber e os Ministros Teori Zavascki e Ricardo Lawandowski reconheceram a exiguidade do prazo de 90 dias para a realização de audiências de custódia em todo o território nacional, sugerindo que ficasse a cargo do CNJ fixar tal prazo. Os referidos Ministros foram vencidos nesse aspecto e a decisão do pedido cautelar acabou fixando o prazo de noventa dias ${ }^{42}$.

41 SILVA, Virgílio Afonso da. "Um voto qualquer?": o papel do ministro relator na deliberação no supremo tribunal federal. Revista Estudos Institucionais. Disponivel em: <https://goo.gl/bdafZD>. Acesso em: $05 \mathrm{dez}$. 2017.

42 BRASIL. Supremo Tribunal Federal. ADPF n ${ }^{0}$ 347. Relator: Marco Auré- 
No tocante à determinação para que a União liberasse as verbas do Fundo Penitenciário Nacional - FUNPEN, abstendo-se de realizar novos contingenciamentos, foram vencidos os Ministros Edson Fachin, Roberto Barroso e Rosa Weber, os quais fixavam o prazo de até 60 dias, a contar da publicação da decisão, para que a União procedesse à adequação para o cumprimento do que fora determinado. O Plenário, entretanto, determinou que o descontigenciamento fosse realizado de forma imediata, sem a concessão de qualquer prazo para adequações.

Por todo o exposto, tem-se que a decisão cautelar da ADPF n 347 em pouco contribui para um ganho hermenêutico, haja vista as inúmeras lacunas argumentativas existentes na decisão, de forma que a ratio está apenas na declaração de existência de um Estado de Coisas Inconstitucional sobre o sistema penitenciário brasileiro, o que é até óbvio diante do estado caótico dessa política pública no país, entretanto não se sabe o que de fato vem a ser o Estado de Coisas Inconstitucional.

São vários os entraves para a utilização do Estado de Coisas Inconstitucional como fundamento de decisão judicial, a começar por uma falta de conceituação desse instituto, dificultando a utilização da decisão cautelar, sob o ponto de vista substancial, como precedente em casos futuros em que haja a constatação de violação massiva e estrutural de direitos fundamentais em razão de omissões não normativas.

Em síntese, verifica-se que a importação do conceito de Estado de Coisas Inconstitucional ocorreu mais como uma manifestação retórica que como uma ideia constitucional capaz de promover uma melhoria na realidade brasileira. Essa conclusão é corroborada pelo fato de que quase um ano depois da ADPF n 347, a mesma Corte ter passado a consi-

lio. Brasília, DF de 2015. Diário Oficial da União. Brasília, 2015. p. 4. 
derara possibilidade do cumprimento antecipado da pena após o julgamento em segundo grau, sem fazer qualquer menção à decisão cautelar da ADPF n 347.

Outro reforço ao simbolismo da decisão cautelar da ADPF n 347 está para além da falta de discussão se as medidas adotadas são de fato as mais adequadas para a superação do quadro de violação massiva e estrutural de direitos fundamentais dos presidiários, mas sim na adoção de medidas contrárias as regulamentações infralegais acerca da política penitenciária.

Nesse ponto, estamos nos referindo ao processo de liberação de verbas do FUNPEN, o qual prevê um plano de desembolso que inclui primeiramente a oitiva das unidades da Federação e de entidades da sociedade civil que atuam no tema das políticas penais. Em seguida, o Ministério da Justiça solicitará ao CNJ a avaliação técnica do plano de desembolso antes da publicação de editais e de chamadas públicas. A liberação de recursos, portanto, apenas ocorrerá se os Estados-membros enviarem propostas para modernização e ampliação dos presídios.

Percebe-se, portanto, que o Supremo emitiu determinações contrárias à legislação infra-constitucional existente, contrariando, inclusive, as previsões da Lei 4.320/64, ou seja, a determinação de imediata liberação de verbas do FUNPEN de pouco ou nada adiantará se os Estados não enviarem propostas de melhoria da política penitenciária.

Conforme afirma Marcelo Neves, a experiência brasileira enquadra-se como um caso típico de modernidade periférica, em que a autonomia operacional do Direito é atingida por intrusões da política, sendo sistematicamente bloqueado pelas pressões advindas do meio social ${ }^{43}$. Nesse

43 NEVES, Marcelo. Entre Têmis e Leviatã: Uma relação difícil. São Paulo: Martins Fontes, 2008, p. 245. 
sentido, acredita-se que a utilização do Estado de Coisas Inconstitucional como fundamento de decisão judicial revela apenas a pressão do sistema social sobre o sistema jurídico, sem real compromisso com a adoção desse instituto para uma aproximação do texto constitucional com a realidade.

Tendo em vista a abertura do sistema jurídico e a sua troca com os demais subsistemas, inclusive com os sistemas jurídicos de outros países, o que se convencionou chamar de transconstitucionalismo, como visto, tem-se que o Estado de Coisas Inconstitucional é incorporado no cenário nacional mediante a absorção, por mera ornamentação, da jurisprudência de um tribunal constitucional por outro, utilizando-a no julgamento de sua própria questão constitucional ${ }^{44}$.

Ocorre que o diálogo constitucional transnacional deve ocorrer por meio de um exercício de transparência metodológica, em que os inputs no sistema jurídico nacional se adequem à realidade deste, restando claro na decisão judicial como foi feita essa compatibilização, por meio das justificações abstratas e concretas, o que não ocorreu no sistema jurídico nacional, comprometendo, inclusive, a formulação da ratio decidendi da incorporação do ECI, o que prejudica a utilização da decisão cautelar da ADPF n 347 enquanto precedente, haja vista baixa força hermenêutica de seus pressupostos materiais, incluindo a crítica doutrinária, a qual tem se mostrado bastante receosa acerca da utilização do ECI, enquanto fundamento de decisões judiciais ${ }^{45}$.

44 MORAES, Guilherme Peña de. Constitucionalismo Multinacional: uso persuasivo da jurisprudência estrangeira pelos tribunais constitucionais. São Paulo: Atlas, 2015, p. 24 a 27.

45 Nesse sentido, tem-se o posicionamento de Lênio Streck e Martônio Mont'alverne em: STRECK, Lenio Luiz; LIMA, Martonio Mont'alverne Barreto. Estado de Coisas Inconstitucional é uma nova forma de ativismo. 2015. Disponível em: <http://www.conjur.com.br/2015-fev-10/leipoliticas-publicas-estado-social-golpe-caneta>. Acesso em: 22 out. 2017 


\section{CONCLUSÃO}

A ADPF n 347 ainda não foi julgada no mérito, mas na decisão cautelar o plenário da Corte Constitucional decidiu pela obrigatoriedade da realização das audiências de custódia no prazo de noventa dias e o imediato descontingenciamento do FUNPEN. A referida decisão foi publicada no fim de 2015 e as medidas ordenadas pela Suprema Corte ainda não foram implementadas, mantendo-se o quadro de violação massiva dos direitos fundamentais dos presidiários.

Para além, da baixa efetividade da decisão, o Supremo ainda reconheceu a possibilidade de execução provisória da pena após a condenação em segunda instância, por meio do julgamento das ADCs 43 e 44, motivando a referida decisão com base no principio da razoável duração do processo e evidenciando que o sistema jurídico ainda não está devidamente diferenciado do sistema político no Brasil, haja vista a natureza eminentemente política dessa decisão, a qual entra em conflito direto com as disposições da decisão cautelar proferida na ADPF n 347 e fere a lógica que culminou na declaração do Estado de Coisas Inconstitucional.

Deve-se considerar, ainda, os inúmeros vácuos hermenêuticos existentes na decisão cautelar da ADPF n 347, o que constitui verdadeiro entrave para a utilização dessa decisão enquanto precedente a fundamentar casos futuros, não obstante a obrigatoriedade de observância a decisões do Supremo por outros juízes e tribunais disposta no Artigo 927, inciso I do Código de Processo Civil.

e Raffaele de Giorgi, José Eduardo Faria e Celso Capilongo em: GIORGI, Raffaele de; FARIA, José Eduardo; CAPILONGO, Celso. Estado de Coisas Inconstitucional. 2015. Disponível em: <http://opiniao.estadao.com.br/ noticias/geral,estado-de-coisas inconstitucional,10000000043>. Acesso em: 22 out. 2017. 
Percebe-se, portanto, que da forma como foi declarado, o ECI apresenta baixa chance de efetivamente contribuir na superação das omissões inconstitucionais não normativas, uma vez que o Supremo fixou as medidas a serem adotadas sem estabelecer qualquer diálogo com os demais poderes constitucionais e nem com os setores da sociedade civil envolvidos na proteção dos direitos fundamentais dos presos, fixando ordens contrárias às próprias regras infraconstitucionais e sem estabelecer mecanismos de fiscalização da decisão, importando, aparentemente, a versão mais ineficiente do instituto, referente ao seu estágio inicial de seu desenvolvimento na Colômbia.

Conclui-se, então, que a decisão cautelar proferida na ADPF n 347, que culminou na importação do ECI para o ordenamento brasileiro, constituiu uma decisão meramente simbólica, sem pretensões de alterar a realidade nacional.

\section{Referências bibliográficas}

ACKERMAN, Bruce. The Rise of World Constitutionalism. 83 Va. L. Rev. 771 (1997).

BRASIL. MINISTÉRIO DA JUSTIÇA. DEPEN - Departamento Penitenciário Nacional. Levantamento nacional de informações penitenciárias - INFOPEN. Brasília: Ministério da Justiça - DEPEN, junho de 2014.

. Supremo Tribunal Federal. Ação Declaratória de Constitucionalidade 43 e 44. Relator: Ministro Marco Aurélio. Tribunal Pleno. Data de julgamento: 05/10/2016. Data de publicação: DJE 11/10/2016.

.Supremo Tribunal Federal. ADPF N ${ }^{\circ}$ 347. Relator: Marco Aurélio. Brasília, DF de 2015. Diário Oficial da União. Brasília, 2015.

CAMPOS, Carlos Alexandre de Azevedo. Estado de Coisas 
Inconstitucional. Salvador: Juspodium, 2016.

CÁRDENAS, Blanca Raquel. Contornos jurídico-fácticos del Estado de Cosas Inconstitucional. Colombia: U. Externado de Colombia, 2011.

COLOMBIA. Gov. Constitución Política de Colombia.

Disponível em:<http://www.corteconstitucional.gov.co/ inicio/Constitucion \% 20politica \% 20de\%20Colombia \%20 -\% 202015.pdf>. Acesso em: 03 dez. 2017.

CORREDOR, Róman J. Duque. Estado de Derecho y justicia: desviaciones y manipulaciones. El Estado de cosas inconstitucional, Provincia Especial, 2006.

DIAS, Roberto; MOHALLEM, Michael Freitas. O diálogo jurisdicional sobre direitos humanos e a ascensão da rerde global de cortes constitucionais. In PIOVESAN, Flávia. SALDANHA, Jânia Maria Lopes. Diálogos jurisdicionais e cortes constitucionais. São Paulo: Gazeta Jurídica. 2016.

BERTEA, Stefano, SARRA, Claudio, Foreign Precedents in Judicial Argument: A Theoretical Account (July 16, 2014). University of Leicester School of Law Research Paper No. 14-20. Available at SSRN: https:/ /ssrn.com/abstract=2467155 or http:/ / dx.doi.org/10.2139/ssrn.2467155 FISS, Owen M. Foreword: The Forms of Justice, Harvard Law Review, v. 93, n. 1, 1979.

DORSEN, Norman. The relevance of foreign legal materials in U.S. constitutional cases: A conversation between Justice Antonin Scalia and Justice Stephen Breyer. International Journal of Constitutional Law, Volume 3, Issue 4, 1 October 2005, Pages 519-541, https:// doi.org/10.1093/icon/moi032.

DWORKIN, Ronald. O Império do Direito. São Paulo: Martins Fontes, 1999.

FREIRE, Alonso. Importação de ideias constitucionais. 2015. Disponível em: <http://www.osconstitucionalistas. 
com.br/importacao-de-ideias-constitucionais>. Acesso em: 03 dez. 2017.

. Integridade transnacional dos direitos humanos. Revista de Informação Legislativa. Brasília. Ano 53. № 209. Jan./mar. 2016. p. 255-275.

GIORGI, Raffaele de; FARIA, José Eduardo; CAPILONGO, Celso. Estado de Coisas Inconstitucional. 2015. Disponível em: <http:/ / opiniao.estadao.com.br/noticias/geral,estado-de-coisas inconstitucional,10000000043>. Acesso em: 22 out. 2017.

HABER, Carolina. Protagonismo do Supremo na política carcerária: necessário, mas insuficiente. In: FALCÃO, Joaquim; ARGUELHES, Diego Werneck; RECONDO, Felipe. Onze Supremos: O Supremo em 2016. Belo Horizonte: Fgv, 2017. JACOBSOHN, Gary Jeffrey. Constitutional Identity. Cambridge, Mass.: Harvard University Press, 2010.

LOPES FILHO, Juraci Mourão. Os precedentes judiciais no constitucionalismo brasileiro contemporâneo. 2. ed. Salvador: Juspodium, 2016.

MORAES, Guilherme Peña de. Constitucionalismo Multinacional: uso persuasivo da jurisprudência estrangeira pelos tribunais constitucionais. São Paulo: Atlas, 2015.

MOTTA, Francisco José Borges; RAMIRES, Maurício. O novo Código de Processo Civil e a Decisão Jurídica Democrática: Como e por que aplicar precedentes com coerência e integridade. In: STRECK, Lênio Luiz; ALVIM, Eduardo Arruda; LEITE, Geroge Salomão. Hermenêutica e Jurisprudência no Novo Código de Processo Civil: Coerência e Integridade. São Paulo: Saraiva, 2016. Cap. 4.

NEVES, Marcelo. Transconstitucionalismo. São Paulo: Martins Fontes. 2012.

. Do diálogo entre as cortes supremas e a Corte 
Interamericana de Direitos Humanos ao transconstitucionalismo na América Latina. Revista de Informação legislativa. Ano 51, Número 201, ja/mar. 2014. p. 193-214.

PEREIRA, Jane Reis Gonçalves; GONÇALVES, Gabriel Accioly. Inconstitucionalidade sistêmica e multidimensional: transformações no diagnóstico das violações à Constituição. Juris Poiesis, Rio de Janeiro, v. 18, p.130-159, jan. 2015. Anual.

PETTER, Lafayete Josué. Direito Financeiro. 5. ed. Porto Alegre: Verbo Jurídico, 2010.

RAUTENBACH, Christa. The South African constitutional court's use of foreign precedent in matters of religion: without fear or favour? Potchefstroom Electronic Law Journal/ Potchefstroomse Elektroniese Regsblad. Vol 18, No 5 (2015) ROCHA, Leonel Severo, TONET, Fernando. A interconstitucionalidade como produção jurídica descentralizada dentro das novas observações estatais. Revista Brasileira de Estudos Políticos | Belo Horizonte | n. 115 | pp. 473-496 | jul./dez. 2017.

SHAPIRO, S. J. Legality. Cambridge: Harvard University Press, 2011.

SILVA, Virgílio Afonso da. “Um voto qualquer?”: o papel do ministro relator na deliberação no supremo tribunal federal. Revista Estudos Institucionais. Disponivel em: <https:// goo.gl/bdafZD>. Acesso em: 05 dez. 2017.

SLAUGHTER, Anne-Marie. A Global Community of Courts. 44 Harvard International Law Journal 191 (2003) STARGER, Colin. The Dialectic of Stare Decisis Doctrine. In: PETERS, Cristopher J. Precedent in the United States Supreme Court. Ebook: Springer, 2013.

STRECK, Lenio Luiz. Estado de Coisas Inconstitucional é uma nova forma de ativismo. 2015. Disponível em: <ht- 
tps://www.conjur.com.br/2015-out-24/observatorio-constitucional-estado-coisas-inconstitucional-forma-ativismo>. Acesso em: 03 dez. 2017.

Lenio Luiz; LIMA, Martonio Mont'alverne Barreto. Estado de Coisas Inconstitucional é uma nova forma de ativismo. 2015. Disponível em: <http://www.conjur. com.br/2015-fev-10/lei- politicas-publicas-estado-social-golpe-caneta>. Acesso em: 22 out. 2017.

TUSHNET, Mark. The Possibilities of Comparative Constitutional Law. 108 Yale Law Journal. 1225 (1999).

V. NEFF, Emma C. From Equal Protection to the Right to Health: Social and Economic Rights, Public Law Litigation, and How an Old Framework Informs a New Generation of Advocacy, Columbia Journal of Law and Social Problems, v. 43, n. 2, 2009.

YOO, John, Peeking Abroad?: The Supreme Court's Use of Foreign Precedents in Constitutional Cases. university of Hawaii Law Review, 2004. Available at SSRN: https:/ / ssrn. com/abstract $=615962$

Recebido em 01/05/2018.

Aprovado em 21/09/2018.

Juraci Mourão Lopes Filho

E-mail: juracimourao@gmail.com

Isabelly Cysne Augusto Maia

E-mail: isabellycysne@gmail.com 
